Original Research Article

\title{
Complementary and alternative medicine use among type $\mathbf{2}$ diabetes patients in a tertiary care hospital
}

\author{
Shamiya Sadiq*, Kanika Khajuria, Vijay Khajuria
}

Department of Pharmacology, Govt. Medical College and Hospital, Jammu, Jammu and Kashmir, India

Received: 12 September 2017 Accepted: 26 September 2017

*Correspondence to:

Dr. Shamiya Sadiq, Email: drshamiya31621@ gmail.com

Copyright: (C) the author(s), publisher and licensee Medip Academy. This is an openaccess article distributed under the terms of the Creative Commons Attribution NonCommercial License, which permits unrestricted noncommercial use, distribution, and reproduction in any medium, provided the original work is properly cited.

\begin{abstract}
Background: Complementary and alternative medicine (CAM) use is prevalent among chronic diseases like Diabetes mellitus (DM). Therefore, the aim was to study the pattern of CAM use among Type2DM in our set up.

Methods: The study was done in diabetic patients attending OPD of Government medical college hospital over a period of 2 months. Patients who gave consent were subjected to a pre-structured questionnaire which consisted of two parts pertaining to socio-demographic profile and CAM usage details.

Results: Out of 280 patients enrolled in the study, 110 admitted being CAM users along with conventional Anti-Diabetic treatment. The CAM users were mostly females $(56.36 \%)$ and were from rural background $(70.90 \%)$. CAM was prevalent in educated patients $(90.90 \%)$ more than illiterates $(9.09 \%)$. Ayurveda (44.54\%) was the most common type of CAM used and relatives $(58.18 \%)$ provided main source of CAM information. $32.72 \%$ patients thought that CAM is safe, effective $(20.90 \%)$ and less costly (19.09\%). Only $16.36 \%$ patients disclosed regarding their CAM usage to the attending physician while majority $(83.63 \%)$ were nonrevealers. The results suggest that patients should be encouraged to reveal to their physician regarding CAM as it can avoid possibility of interactions.

Conclusions: CAM is prevalent in T2DM and more so in females from rural areas. Ayurveda was the most widely type of CAM used and majority of patients did not disclose to the treating physician regarding CAM usage.
\end{abstract}

Keywords: Anti diabetic drugs, Complementary and alternative medicine, CAM, Diabetes mellitus, Tertiary care

\section{INTRODUCTION}

Complementary and alternative medicine (CAM) use is prevalent globally among patients and is much higher in the developing countries. Complementary medicine refers to the use of non-conventional therapy, in conjunction with regular treatment, while alternative medicine refers to the use of non-conventional treatment. CAM comprises over 100 forms of treatment. ${ }^{1}$

The chronic diseases require prolonged therapy and these patients usually seek alternative medicines. Diabetes mellitus (DM) a chronic debilitating condition is associated with significant morbidity and mortality as it cannot be permanently cured and requires lifelong medicines. The modern medicines alone may not meet the needs of these patients and consequently some patients adopt CAM with addition to modern therapy. ${ }^{2,3} \mathrm{DM}$ patients are 1.6 times more likely to use $\mathrm{CAM} .{ }^{4}$ India too has many religious and spiritual beliefs and these are more likely to influence the usage of CAM. India is the birth place of one of the oldest systems of medicine, Ayurveda, which had its origin around 2000 years back and is the most commonly practiced form of CAM. About $80 \%$ Indian patients use ayurvedic drugs particularly in chronic illnesses. Besides, Ayurveda, Yoga, Naturopathy, Unani, Sidda and Homeopathy are other forms of CAM practised 
in India. According to studies conducted in different states of India CAM is prevalent $63 \%-68 \%$ in patients with DM. ${ }^{1,5,6}$

The efficacy of CAM in these diseases is still not validated and some type of CAM may be ineffective and pharmacologically incompatible with patient's antidiabetic medications or may even can cause interactions. This situation is further compounded by the fact that many of these patients do not disclose their CAM use to their physicians putting them at risk of ADRs and interactions. ${ }^{7-9}$ Therefore, it is of utmost importance that there should be clarity among the physicians so that they can make safe choices and avoid interactions with CAM. Thus, the present trial was undertaken to evaluate the usage of CAM in patients of Type 2 diabetes mellitus $\left(\mathrm{T}_{2} \mathrm{DM}\right)$ and factors influencing CAM usage.

\section{METHODS}

The current study was conducted amongst patients of $\mathrm{T}_{2} \mathrm{DM}$ attending the OPD of Govt Medical College, Hospital Jammu. The study was reviewed and approved by the Institutional ethics committee vide order number IEC/Thesis/Research/I ${ }_{53}-\mathrm{C} / 2015 / 232$ dated $4^{\text {th }}$ November 2015. The participants were informed about purpose, procedure and their rights. They were also assured that information will be strictly confidential and an informed consent was taken prior to commencement of the study. A total of 280 patients of DM over a period of 2 months on conventional treatment were screened and 110 patients were found to be using CAM. These 110 patients were evaluated for CAM parameters and were subjected to the questionnaire. Results obtained were tabulated in percentage. A patient was termed a CAM user if he/she had ever tried CAM for DM till the time of the study. A CAM non-user was defined as one who had never used any CAM therapy.

The questionnaire consisted of 2 parts: The first part pertained to a collection of socio-demographic information of the patient (age, gender, residence, occupation, marital status, education, socio economic status, duration of disease, use of anti-diabetic drugs) and number of CAM user and non-users.

The second part addressed questions related to CAM its type and pattern, which included knowledge of CAM, initiation of CAM use, type of CAM satisfaction/dissatisfaction related to its use, reason for use, duration of disease in relation to CAM, side effects. Patients were also asked about the source of their CAM awareness, who advised use of CAM and whether they informed their doctor regarding CAM usage.

\section{Inclusion criteria}

Patients who were above 40 years of age having $\mathrm{T}_{2} \mathrm{DM}$ with minimum duration of one year and gave informed consent. Patients using CAM along with conventional antidiabetic medications.

\section{Exclusion criteria}

- Patients who could not complete the questionnaire process.

- $\quad$ Patients who did not give informed consent.

\section{Statistical analysis}

Analysis was carried out and the data was expressed in $\mathrm{n}$ (\%). Chi-sq test was applied for some of the parameters to prove their statistical significance. P-value $<0.05$ was considered significant.

\section{RESULTS}

Total $280 \mathrm{~T}_{2} \mathrm{DM}$ patients consented to participate in the study of which 110 were CAM users (39.28\%) and $170(60.71 \%)$ were Non-CAM users. Out of the total 280 patients $48.21 \%$ were females and $51.78 \%$ were males. Most of CAM users belonged to rural areas (70.90\%), having low socioeconomic status $(89.09 \%)$, leading an active life $(92.72 \%)$ and between 40 to 59 years $(52.72 \%)$ of age. Maximum CAM users were between 40 to 59 $(52.72 \%)$ years of age (Table 1$)$.

The patterns of CAM use among patients of diabetes revealed that majority of the patients $(91.81 \%)$ were aware about CAM. Females were predominantly CAM users $(56.36 \%)$. Patients with less than eight years duration of disease $(56.36 \%)$ were more prone to use CAM. Most of the patients $(92.72 \%)$ started using CAM after their antidiabetic treatment. Ayurveda $(44.54 \%)$ was the most common CAM modality used followed by Naturopathy $(10.09 \%)$. Relatives $(58.18 \%)$ were the main source for providing information regarding CAM. Only (16.36\%) CAM users admitted using CAM to their physicians while mostly $(83.63 \%)$ users did not disclose. The most common reason $(41.81 \%)$ stated for not revealing CAM use was the fear of disapproval by the physician (Table 2).

The most common reason for using CAM as reported by $32.72 \%$ users was its safety. Effectiveness $(20.90 \%)$ and low cost $(19.09 \%)$ of CAM were the other reasons stated for using CAM (Table 3).

\section{DISCUSSION}

CAM is quite prevalent in the developing countries particularly in the chronic diseases which usually require prolonged therapy with conventional medicines. Chang HYA et al has shown that majority of the Type 2 diabetic patients in Taiwan use both conventional and CAM in management of their illness. ${ }^{10}$ Diabetes is one of the most common disease in India according to recent reports its prevalence ranges from $5-17 \%$ and is a major health problem that requires regular medications. India will be home to 69.1 million people with DM, the second highest 
number of cases after China and will be aptly described as the capital city of Diabetes. ${ }^{11,12}$ This situation mostly encourages the patients to seek alternative therapy mostly in addition to conventional medicines influenced by their socio-cultural beliefs.

In this backdrop numbers of the studies have been done to evaluate the prevalence of CAM in DM in different cities of India like Uttar Pradesh, Kerala, Maharashtra where the incidence ranges as high as 63\%-68\%.,6,12 In the current study out of total 280 patients, $39.28 \%$ patients were CAM users which is consistent with the observations reported in number of studies those reported CAM users to be $29 \%$, $39 \%$ and $40 \%$ respectively. ${ }^{2,12,13}$ However, our observation was inconsistent with the results of other researchers where CAM users were higher. ${ }^{5,6}$ The frequency of CAM users before Anti-diabetic treatment were $7.27 \%$ and after conventional treatment CAM usage increased to $92.72 \%$ in our study which is almost similar to observations made by others. ${ }^{10,14}$

Females $(56.36 \%)$ used CAM more in our setup than males probably the reason being that females are easily influenced by cultural beliefs, social beliefs, relatives etc. Our results are in concurrence to the results of earlier studies..$^{10,13,15,16}$ In the present study, nearly $71 \%$ patients were from rural background who used CAM. People in rural areas mostly seek CAM because of their cultural and holistic beliefs and most of them have joint families which are more prone to be influenced by their near relatives. In our study also, relatives (59\%) were the main source of information regarding use of CAM.

Table 1: Socio-demographic profile of patients of $T_{2} D M(n=280)$.

\begin{tabular}{|c|c|c|c|c|c|}
\hline Parameter & & $\begin{array}{l}\text { CAM users } \\
\mathrm{n}=\mathbf{1 1 0}\end{array}$ & $\begin{array}{l}\text { Non-CAM users } \\
\mathbf{n}=\mathbf{1 7 0}\end{array}$ & $\begin{array}{l}\text { CAM users } \\
\text { P value }\end{array}$ & $\begin{array}{l}\text { Non-CAM users } \\
\text { P value }\end{array}$ \\
\hline Use of CAM & & $110(39.28 \%)$ & $170(60.71 \%)$ & $\begin{array}{l}x^{2}=25.714 \\
d f=1 \\
p<0.0001\end{array}$ & \\
\hline Sex & $\begin{array}{l}\text { Females } \\
\text { Males }\end{array}$ & $\begin{array}{l}62(56.36 \%) \\
48(43.63 \%)\end{array}$ & $\begin{array}{l}73(42.94 \%) \\
97(57.05 \%)\end{array}$ & $\begin{array}{l}x^{2}=12.291 ; d f=1 ; \\
p<0.0005\end{array}$ & $\begin{array}{l}x^{2}=6.776 ; d f=1 ; \\
p=0.0092\end{array}$ \\
\hline Residence & $\begin{array}{l}\text { Rural } \\
\text { Urban }\end{array}$ & $\begin{array}{l}78(70.90 \%) \\
32(29.09 \%)\end{array}$ & $\begin{array}{l}105(61.76 \%) \\
65(38.23 \%)\end{array}$ & $\begin{array}{l}x^{2}=38.47 ; d f=1 ; \\
p<0.0001\end{array}$ & $\begin{array}{l}x^{2}=18.824 ; d f=1 ; \\
p<0.0001\end{array}$ \\
\hline Age (in years) & $\begin{array}{l}40-59 \\
60-69 \\
70-79 \\
>80\end{array}$ & $\begin{array}{l}58(52.72 \%) \\
42(38.18 \%) \\
08(7.27 \%) \\
02(1.81 \%)\end{array}$ & $\begin{array}{l}60(35.29 \%) \\
86(50.58 \%) \\
15(8.82 \%) \\
09(5.29 \%)\end{array}$ & & \\
\hline Marital status & $\begin{array}{l}\text { Married } \\
\text { Unmarried }\end{array}$ & $\begin{array}{l}106(96.36) \\
04(3.63 \%)\end{array}$ & $\begin{array}{l}160(94.11 \%) \\
10(5.88 \%)\end{array}$ & $\begin{array}{l}x^{2}=189.164 \\
d f=; p<0.0001\end{array}$ & $\begin{array}{l}x^{2}=264.706 ; d f=1 ; \\
p<0.0001\end{array}$ \\
\hline Religion & $\begin{array}{l}\text { Hindus } \\
\text { Muslims } \\
\text { Others }\end{array}$ & $\begin{array}{l}77(70 \%) \\
28(25.45 \%) \\
04(3.63 \%)\end{array}$ & $\begin{array}{l}109(64.11 \%) \\
40(23.52 \%) \\
21(12.35 \%)\end{array}$ & & \\
\hline Occupation & $\begin{array}{l}\text { Females- } \\
\text { Non-working } \\
\text { Working } \\
\text { Male - } \\
\text { Non-working } \\
\text { Working }\end{array}$ & $\begin{array}{l}54(49.09 \%) \\
14(12.72 \%) \\
0 \\
42(38.18 \%)\end{array}$ & $\begin{array}{l}62(36.47 \%) \\
11(6.47 \%) \\
08(4.70 \%) \\
89(52.35 \%)\end{array}$ & & \\
\hline Education & $\begin{array}{l}>\text { high school } \\
<\text { high school } \\
\text { Illiterate }\end{array}$ & $\begin{array}{l}48(43.63 \%) \\
52(47.27 \%) \\
10(9.09 \%)\end{array}$ & $\begin{array}{l}71(41.76 \%) \\
96(56.47 \%) \\
12(7.05 \%)\end{array}$ & & \\
\hline $\begin{array}{l}\text { Socioeconomic } \\
\text { status }\end{array}$ & $\begin{array}{l}<10,000 \\
\geq 10,000\end{array}$ & $\begin{array}{l}98(89.09 \%) \\
12(10.90 \%)\end{array}$ & $\begin{array}{l}101(59.41 \%) \\
79(46.47 \%)\end{array}$ & $\begin{array}{l}x^{2}=134.473 ; d f=1 ; \\
p<0.0001\end{array}$ & $\begin{array}{l}x^{2}=5.378 ; d f=1 \\
p=0.0204\end{array}$ \\
\hline Life-Style & $\begin{array}{l}\text { Active life } \\
\text { Sedentary life }\end{array}$ & $\begin{array}{l}102(92.72 \%) \\
08(7.27 \%)\end{array}$ & $\begin{array}{l}149(87.64 \%) \\
21(12.35 \%)\end{array}$ & $\begin{array}{l}x^{2}=160.655 ; d f=1 ; \\
p<0.0001\end{array}$ & $\begin{array}{l}x^{2}=192.753 ; d f=1 ; \\
p<0.0001\end{array}$ \\
\hline $\begin{array}{l}\text { Daily routine } \\
\text { affected by } \\
\text { disease }\end{array}$ & $\begin{array}{l}\text { No } \\
\text { Yes }\end{array}$ & $\begin{array}{l}102(92.72 \%) \\
08(7.27 \%)\end{array}$ & $\begin{array}{l}143(84.11 \%) \\
27(15.88 \%)\end{array}$ & $\begin{array}{l}x^{2}=160.655 ; d f=1 ; \\
p<0.0001\end{array}$ & $\begin{array}{l}x^{2}=158.306 ; d f=1 ; \\
p<0.0001\end{array}$ \\
\hline Co-morbidity & $\begin{array}{l}\text { No } \\
\text { Yes }\end{array}$ & $\begin{array}{l}62(56.36 \%) \\
48(43.63 \%)\end{array}$ & $\begin{array}{l}73(42.94 \%) \\
97(57.05 \%)\end{array}$ & $\begin{array}{l}x^{2}=3.564 ; d f=1 ; \\
p=0.0591\end{array}$ & $\begin{array}{l}x^{2}=6.776 ; d f=1 ; \\
p=0.00092\end{array}$ \\
\hline $\begin{array}{l}\text { Conventional } \\
\text { medication for } \\
\mathrm{T}_{2} \mathrm{DM}\end{array}$ & $\begin{array}{l}\text { Oral hypoglycaemic } \\
\text { Insulin injections } \\
\text { Both }\end{array}$ & $\begin{array}{l}107(96.63 \%) \\
02(1.81 \%) \\
01(4.54 \%)\end{array}$ & $\begin{array}{l}160(94.11 \%) \\
08(4.70 \%) \\
02(1.17 \%)\end{array}$ & & \\
\hline
\end{tabular}


Table 2: Pattern of CAM in diabetic patients $(n=110)$.

\begin{tabular}{|c|c|c|c|}
\hline Parameter & & n $(\%)$ & p-value \\
\hline $\begin{array}{l}\text { Knowledge or awareness } \\
\text { about CAM }\end{array}$ & $\begin{array}{l}\text { Present } \\
\text { Absent }\end{array}$ & $\begin{array}{l}101(91.81 \%) \\
09(8.1 \%)\end{array}$ & $\begin{array}{l}\mathrm{x}^{2}=153.89 \\
\mathrm{DF}=1 ; \mathrm{p}<0.0001\end{array}$ \\
\hline Gender of CAM users & $\begin{array}{l}\text { Females } \\
\text { Males }\end{array}$ & $\begin{array}{l}62(56.36 \%) \\
48(43.63 \%)\end{array}$ & $\begin{array}{l}x^{2}=3.564 ; D F=1 \\
p=0.0591\end{array}$ \\
\hline Initiation CAM use & $\begin{array}{l}\text { After using Anti-diabetic treatment } \\
\text { Before using Anti-diabetic treatment }\end{array}$ & $\begin{array}{l}102(92.72 \%) \\
08(7.27 \%)\end{array}$ & $\begin{array}{l}x^{2}=160.65 ; D F \\
=1 ; p<0.0001\end{array}$ \\
\hline $\begin{array}{l}\text { Duration of disease in } \\
\text { relation to CAM use }\end{array}$ & $\begin{array}{l}<8 \text { year } \\
>8 \text { year }\end{array}$ & $\begin{array}{l}62(56.36 \%) \\
48(43.63 \%)\end{array}$ & $\begin{array}{l}x^{2}=3.564 ; D F=1 \\
p=0.0591\end{array}$ \\
\hline Type of CAM used & $\begin{array}{l}\text { Ayurveda } \\
\text { Naturopathy } \\
\geq 2 \text { types of CAM modalities } \\
\text { Herbal medicines } \\
\text { Bittergourd } \\
\text { Fenugreek seeds } \\
\text { Yoga }\end{array}$ & $\begin{array}{l}49(44.54 \%) \\
12(10.90 \%) \\
12(10.90 \%) \\
10(9.09 \%) \\
10(9.09 \%) \\
09(8.18 \%) \\
08(7.27 \%)\end{array}$ & \\
\hline $\begin{array}{l}\text { Source of information } \\
\text { regarding CAM use }\end{array}$ & $\begin{array}{l}\text { Relatives } \\
\text { Friends } \\
\text { Neighbours } \\
\text { Media }\end{array}$ & $\begin{array}{l}64(58.18 \%) \\
22(20 \%) \\
16(14.54 \%) \\
08(7.27 \%)\end{array}$ & \\
\hline CAM Provider & $\begin{array}{l}\text { Self } \\
\text { Homeopath } \\
\text { Yoga instructor }\end{array}$ & $\begin{array}{l}98(89.09 \%) \\
08(7.27 \%) \\
04(3.63 \%)\end{array}$ & \\
\hline CAM revealers & $\begin{array}{l}\text { To ensure proper relief } \\
\text { Physician enquired }\end{array}$ & $\begin{array}{l}10(9.09 \%) \\
08(7.27 \%)\end{array}$ & $\begin{array}{l}x^{2}=0.444 ; D F=1 \\
p=0.5050\end{array}$ \\
\hline CAM non- revealers & $\begin{array}{l}\text { Fear of disapproval by the physician } \\
\text { They feel CAM is safe, no need to discuss its use } \\
\text { Didn't find necessary to tell physician } \\
\text { Not enquired by physician }\end{array}$ & $\begin{array}{l}46(41.81 \%) \\
22(20 \%) \\
17(15.45 \%) \\
07(6.36 \%)\end{array}$ & \\
\hline Outcome of CAM use & $\begin{array}{l}\text { Blood sugar controlled } \\
\text { Failure to control blood sugar }\end{array}$ & $\begin{array}{l}108(98.18 \%) \\
02(1.81 \%)\end{array}$ & $\begin{array}{l}x^{2}=0.000 ; D F=1 ; \\
p=1.000\end{array}$ \\
\hline
\end{tabular}

Table 3: Reasons for starting CAM (n=110).

\begin{tabular}{|ll|}
\hline Reasons & $\mathbf{n \%}$ \\
\hline CAM is safe & $36(32.72 \%)$ \\
\hline Effective & $23(20.90 \%)$ \\
\hline Less costly & $21(19.09 \%)$ \\
\hline To improve body health & $13(11.81 \%)$ \\
\hline $\begin{array}{l}\text { Dissatisfaction from conventional } \\
\text { medicines }\end{array}$ & $7(6.36 \%)$ \\
\hline$\geq 2$ reasons for starting CAM & $10(9.09 \%)$ \\
\hline
\end{tabular}

Evaluation of the type of CAM use revealed Ayurveda was the most common CAM modality used by $44.54 \%$ patients followed by Naturopathy $10.09 \%$, herbal medicines and bitter gourd $9.09 \%$ each and fenugreek seeds $8.18 \%$. This is due to the much acceptance of these alternative pathies in rural areas than urban. The current study had maximum CAM users from rural background $(71 \%)$. The Ayurveda dispensaries those provide free medicines are more concentrated in the rural areas. Our observations are consistent with the results obtained from studies done by other researchers who in their studies reported Ayurveda and Naturopathy to be the most common CAM modalities used followed by herbal medicine, bitter gourd and fenugreek seeds.

Relatives were the main source of information regarding CAM use while ineffectiveness of the conventional medicines and thinking CAM to be more safe and effective were the prime reasons cited for initiation of CAM therapy. ${ }^{6,12,17,18}$ The participants of the current study revealed that most important reasons for using CAM was the expectation that CAM will reduce their symptoms, avoid complications besides being safe. Among CAM users only small proportions of the patients $(2 \%)$ did experience difficulty in controlling their blood-sugar levels inspite of addition of CAM modality to their conventional Anti-diabetic medications. These findings are in concurrence with previous studies those also observed CAM use to be safe, effective, cheap and prevent complications. ${ }^{2,5,15,19}$

In the present study most of the patients $(83.63 \%)$ did not reveal to their health care professional about CAM usage. Only $16.36 \%$ of the patients disclosed the use of CAM to their physician. Among the non-revealers $41.8 \%$ feared 
disapproval of CAM use by the physician which was their main concern while $22 \%$ thought CAM was safe so need not to disclose to the physician. This is quite expected as numbers of patients were more from the rural background and of lower literacy rates.

Monica et al 2016 in their study observed that most of the CAM users belonged to rural background $(67 \%)$ and started using CAM to get quick and additional relief $(86 \%)$ from their symptoms. $91 \%$ patients in their study did not disclose CAM use fearing discouragement by their doctor and believing CAM to be safe and effective. These findings are almost similar to the results of present study. ${ }^{2}$

However, contrary to the beliefs as depicted in the current study, the CAM is not absolutely safe as there is always a potential risk of interactions with the conventional Antidiabetic medications as they can lead to life threatening hypoglycaemia.

\section{CONCLUSION}

The current study revealed CAM is prevalent $(39.28 \%)$ in diabetics. CAM was more in females and patients with rural background. Ayurveda was the most widely used type of CAM. Relatives were the main source of CAM information but the main highlight of the study was that only $16.36 \%$ patients revealed to the treating physician regarding their CAM use. This underscores that physicians should take a detailed history and must explore the usage of CAM as such can lead to interactions with conventional Anti-diabetic medications.

\section{Funding: No funding sources}

Conflict of interest: None declared

Ethical approval: The study was approved by the Institutional Ethics Committee

\section{REFERENCES}

1. Sadiq S, Kaur S, Khajuria V, Gupta S, Sharma A. Complementary and alternative medicine use in medical OPD patients of rheumatoid arthritis in a tertiary care hospital. Natl J Physiol Pharm Pharmacol. 2016;6(4):305-9.

2. Monica N, Jayanthi CR, Praveen P. Use and satisfaction of complementary and alternative medicine among diabetic patients in a tertiary care hospital. Int $\mathrm{J}$ Basic Clin Pharmacol. 2016;5:2521-7.

3. Egede LE, Zheng D, Ye X, Silverstein MD. The prevalence and pattern of complementary and alternative medicine use in individuals with diabetes. Diabetes care. 2002;25:2.

4. Alfian SD, Sukandar H, Arisanti N, Abdulah R. Complementary and alternative medicine use decreases adherence to prescribed medication in diabetes patients. Ann Trop Med Public Health. 2016;9:174-9.

5. Kumar D, Bajaj S, Mehrotra R. Knowledge, attitude and practice of complementary and alternative medicines for diabetes. Public Health. 2006;120(8):705-11.
6. Bhalerao MS, Bolshete PM, Swar BD, Bangera TA, Kolhe VR, Tambe MJ et al. Use of and satisfaction with complementary and alternative medicine in four chronic diseases: a cross-sectional study from India. Natl Med J India. 2013;26(2):75-8.

7. Ernst E. Complementary medicine: its hidden risks. Diabetes Care. 2001;24(8):1486-8.

8. Huri HZ, Lian GTP, Hussain S, Pendek R, Widodo RT. A survey amongst complementary and alternative medicine (CAM) users with type 2 diabetes. Int $\mathbf{J}$ Diabetes Metabolism. 2009;17:9-15.

9. Birdee GS, Yeh G. Complementary and alternative medicine therapies for diabetes: a clinical review. Clin Diabetes. 2010;28(4):147-55.

10. Chang HY, Wallis M, Tiralongo E. Use of complementary and alternative medicine among people with type 2 diabetes in Taiwan: a cross-sectional survey. Evidence-Based Complementary and Alternative Medicine. 2010;2011:983792.

11. Tripathy JP, Thakur JS, Jeet G, Chawla S, Jain S, Pal A, et al. Prevalence and risk factors of diabetes in a large community-based study in North India: results from a STEPS survey in Punjab, India. Diabetol Metab Syndr. 2017;9:8.

12. Vishnu N, Mini GK, Thankappan KR. Global Health, Epidemiology and Genomics. 2017;2:6(1).

13. Baharom N, Shah SA, Rotina AB. Prevalence of Complementary Alternative Medicine Use among Patients with Type II Diabetes in Negeri Sembilan, Malaysia. Med \& Health. 2016;11(2):257-66.

14. Wanchai A, Phrompayak D. Use of Complementary and Alternative Medicine among Thai patients with Type 2 Diabetes.J Integr Med. 2016;14(4):297-305.

15. Sheikhrabori A, Dehghan M, Ghaedi F, Khademi GR. Complementary and Alternative Medicine Usage and Its Determinant Factors Among Diabetic Patients: An Iranian Case. Journal of Evidence-Based Complementary and Alternative Medicine. 2017;22(3):449-54.

16. Ching SM, Zakaria ZA, Paimin F, Jalalian M. Complementary alternative medicine use among patients with type 2 diabetes mellitus in the primary care setting: a cross-sectional study in Malaysia. BMC Complement Altern Med. 2013;13:148.

17. Mohamed H, Abdin J, Lenjawi B Al, Hamadani ZF Al, Schlogl JM. Use of Complementary and Alternative Medicine among patients with Type 2 Diabetes Mellitus in a Newly Developing Country: A Cross-Sectional Study in Qatar. Int J Clin Res Trials. 2016;2:106.

18. Roy V, Gupta M, Ghosh R. Perception, attitude and usage of complementary and alternative medicine among doctors and patients in a tertiary care hospital in India. Indian J of Pharma. 2015;47(2):137.

19. Funnell MM, Anderson RM. Empowerment and selfmanagement of diabetes. Clinical Diabetes. 2004;22:1237.

Cite this article as: Sadiq S, Khajuria K, Khajuria V. Complementary and alternative medicine use among type 2 diabetes patients in a tertiary care hospital. Int J Basic Clin Pharmacol 2017;6:2561-5. 